\title{
Prevalence and Associated Risk Factors of COVID-19 Infection Among Healthcare Workers in a Pandemic Hospital
}

\author{
Pandemi Hastanesinde Çalışan Sağlık Çalışanlarında COVID-19 Enfeksiyonunun \\ Yaygınlığı ve Illişkili Risk Faktörleri
}

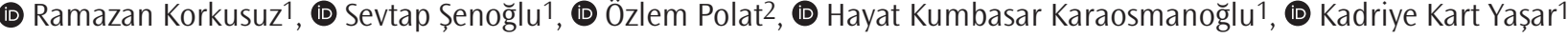 \\ 1 University of Health Sciences Turkey, Bakırköy Dr. Sadi Konuk Training and Research Hospital, Clinic of Infectious Diseases and Clinical Microbiology, \\ İstanbul, Turkey \\ 2University of Health Sciences Turkey, Bakırköy Dr. Sadi Konuk Training and Research Hospital, Clinic of Family Medicine, İstanbul, Turkey
}

\begin{abstract}
Introduction: This study aimed to investigate the prevalence of Coronavirus disease-2019 (COVID-19) infection among healthcare workers in our hospital with the risk factors affecting the transmission and course of the disease and to determine the control measures.

Methods: Medical records of healthcare workers diagnosed with COVID-19, confirmed by polymerase chain reaction (PCR) between 11 March and 30 April 2020, were retrospectively analyzed in our hospital in the center of İstanbul, the city with the highest number of cases in our country. Realtime PCR detection was used to verify the diagnosis of the healthcare workers. A rapid diagnostic test kit for COVID-19 immunoglobulin M (IgM) and IgG antibodies was used in seroconversion analysis.

Results: In our hospital, 4,177 COVID-19 cases confirmed by the laboratory between March 11 and April 302020 were followed. Of the 4177 cases, 165 (3.95\%) were healthcare workers. The majority of healthcare workers with positive test results were nurses (36.3\%), and 118 (71.5\%) of the healthcare workers worked $40 \mathrm{~h}$ or more per week. Thoracic tomography examinations were performed in all infected healthcare workers, and 69 (41.8\%) were diagnosed with pneumonia by the detection of ground patchy lesions.
\end{abstract}

Conclusion: During the epidemic, early training of healthcare workers on the disease, use of personal protective equipment, and infection control are extremely important to reduce the risk of infection among healthcare workers. Periodic screening of asymptomatic healthcare workers can also help protect patients and hospital staff and prevent loss of workforce.

Keywords: Healthcare workers, risk factors, COVID-19

\section{öZ}

Amaç: Bu çalıșmada, hastanemizde görev yapan sağlık çalışanlarının Koronavirüs hastalığı-2019 (COVID-19) enfeksiyonu prevalansı ile hastalığın bulaşını ve seyrini etkileyen risk faktörlerinin araștırılması ve kontrol önlemlerinin belirlenmesi amaçlanmıștır.

Yöntemler: Ülkemizde olguların en fazla olduğu şehir olan İstanbul'un merkezinde olan hastanemizde 11 Mart-30 Nisan 2020 tarihleri arasında polimeraz zincir reaksiyon (PCR) ile konfirme edilmiş COVID-19 tanısı alan sağlık çalışanlarının tıbbi kayıtları retrospektif olarak incelenmiștir. Sağlık çalışanlarının tanıları gerçek zamanlı PCR tespit yöntemi ile konulmuştur. Serokonversiyon incelemesi için hızlı test tanı kiti COVID-19 immünoglobulin M (IgM) ve IgG kullanılmıștır.

Bulgular: Hastanemizde 11 Mart-30 Nisan 2020 tarihleri arasında laboratuvar tarafından konfirme edilmiş 4.177 COVID-19 olgusu takip edilmiştir. Toplam 165’i $(\% 3,95)$ sağlık çalışanıydı. Pozitif olanların çoğunluğunu hemșireler $(\% 36,3)$ olușturmakta ve sağlık çalıșanların 118’i $(\% 71,5)$ haftada 40 saat ve üzerinde çalıșmaktadır. Enfekte sağlık çalıșanın tümüne toraks tomografisi çekilmiş olup 69'unda $(\% 41,8)$ yamasal lezyonlar saptanarak pnömoni tanısı konulmuștur.

Sonuç: Salgın sırasında sağlık çalıșanlarının hastalıkla ilgili bilgilendirilme, kișisel koruyucu ekipman kullanımı ve enfeksiyon kontrolü ile ilgili eğitimlerinin erken dönemde yapılması sağlık çalıșmalarında enfeksiyon riskini azaltma açısından son derece önemlidir. Asemptomatik sağlık çalışanlarının da düzenli aralıklarla taranmasının hastaların ve hastane personelinin korunması açısından faydalı olacağı ayrıca iş gücü kaybının da önüne geçileceği açıktır.

Anahtar Kelimeler: Sağıık çalıșanları, risk faktörleri, COVID-19
Address for Correspondence/Yazıșma Adresi: Ramazan Korkusuz MD, University of Health Sciences Turkey, Bakırköy Dr. Sadi Konuk Training and Research Hospital, Clinic of Infectious Diseases and Clinical Microbiology, İstanbul, Turkey

Phone: +90 5305600499 E-mail: ramazankorkusuz@hotmail.com 0RCID ID: orcid.org/0000-0002-9988-9596

Cite this article as/Atıf: Korkusuz R, Senoğlu S, Polat Ö, Kumbasar Karaosmanoğlu H, Kart Yașar K. Prevalence and Associated Risk Factors of COVID-19 Infection Among Healthcare Workers in a Pandemic Hospital. İstanbul Med J 2021; 22(4): 267-74.

(c) Copyright 2021 by the University of Health Sciences Turkey, Istanbul Training and Research Hospital/istanbul Medical Journal published by Galenos Publishing House.

(C) Telif Hakkı 2021 Să̆lık Bilimleri Üniversitesi istanbul Ĕgitim ve Araştırma Hastanesi/Istanbul Tıp Dergisi, Galenos Yayınevi tarafından basılmıștır.
Received/Geliș Tarihi: 01.11.2020 Accepted/Kabul Tarihi: 19.08.2021 


\section{Introduction}

The new Coronavirus disease-2019 (COVID-19) appeared in late December 2019 in Wuhan, the first epicenter in Hubei Province of the People's Republic of China (1). COVID-19 has a high mortality rate and progresses with severe pneumonia and acute respiratory distress syndrome (2). The responsible virus, named "Severe acute respiratory syndrome-coronavirus-2 (SARS-CoV-2)" by the Coronavirus Working Group of the International Committee on Taxonomy of Viruses because of its close resemblance to SARS-CoVs, is an enveloped RNA virus with a single chain and positive polarity and belongs to the Betacoronavirus family (3). Within 3 months of the first reporting of this new coronavirus, the number of cases exceeded 100,000 worldwide; on March 11, 2020, the World Health Organization (WHO) announced that COVID-19 became a pandemic (4). As of April 30, 2020, the number of cases was 3,090,445 in the world; the first case in Turkey was reported on March 11, 2020, with a total of 117,589 confirmed cases $(5,6)$. The first case of COVID-19 in our hospital was confirmed on March 14, 2020.

SARS-CoV-2 is highly contagious and may have a long incubation period before symptoms such as fever, cough, shortness of breath, and diarrhea appear. SARS-CoV-2 infection may be asymptomatic in some patients, but it may also cause multiple organ failure with lung, heart, and liver involvement in some patients (7). While the fatality rate of the disease in the world is $6.89 \%$, this value is $2.72 \%$ in Turkey (8).

COVID-19 is transmitted through contact and droplets and continues to spread rapidly, and the rate of virus spread (R0) is 2.55-5.7 $(9,10)$. With the surge of COVID-19 cases, infection prevention and control practices in healthcare environments have become necessary. The personal protection of healthcare workers (HCWs) is highly important. The type and amount of personal protective equipment (PPE) that should be used when treating a patient with COVID-19 varies depending on clinical work and environment. Providing direct inpatient treatment to patients with COVID-19, HCWs should wear a medical mask, apron, gloves, and eye protection in the form of goggles or face shield. HCWs performing aerosol-producing procedures should wear an apron/overalls and use an N95 mask instead of a surgical mask (11). During a pandemic, the probability of transmission is very high. Given their significantly long work hours and aerosol-generating procedures, HCWs are highly at risk of contracting the disease and spreading it to inpatients and hospital staff.

WHO-China joint mission reported 3,387 COVID-19 cases among healthcare professionals at 476 medical institutions in China on February 25, 2020 (12). As of April 8, 2020, 22,073 COVID-19 infection cases among HCWs from 52 countries were reported to WHO (13). As of April 30, 2020, the Ministry of Health of our country reported that 7,428 workers were infected among 1 million 100 thousand HCWs (14).

Taking measures to prevent contamination among HCWs and continuous update of their knowledge of specific infections are crucial in the development and implementation of prevention programs. Determining the individual, operational, and institutional characteristics of contamination and preventive measures will be effective in developing the targeted part of prevention programs.
This study aimed to investigate the prevalence of COVID-19 infection among HCWs working in our hospital with the risk factors affecting the transmission and course of the disease and to determine the control measures.

\section{Methods}

Medical records of HCWs diagnosed in our hospital with COVID-19, confirmed by the laboratory between March 11 and April 30, 2020 were retrospectively analyzed. Our hospital, which was appointed as a pandemic hospital at the beginning of the outbreak, is a tertiary healthcare institution with 612 beds, 2737 HCWs (724 physicians, 864 nurses, 10 pharmacists, 978 allied health personnel, and 161 paramedics and technicians) located in the center of İstanbul, the city with the highest number of COVID-19 cases in Turkey.

This research protocol was approved by the University of Health Sciences Turkey, Bakırköy Dr. Sadi Konuk Training and Research Hospital Ethics Committee (approval number: 2020-10, date: 04.05.2020). All participants consisted of clinicians, nurses, and allied health personnel.

HCWs in different departments were divided into two groups according to risk exposure. Those working in departments where interventional medical or surgical procedures that produce respiratory aerosols are performed, including the COVID-19 clinic and intensive care unit, were identified as high-risk groups. Those working in other low-risk clinics and outpatient clinics were considered as the general group. All participants were given an informed consent form.

Clinical signs and symptoms and radiological examination results of the cases were recorded in the hospital system, and data were retrieved from the system retrospectively. Spectrum of illness severity was divided into four groups as defined by WHO (15). Diagnostic criteria for mild COVID-19 include mild clinical symptoms without evidence of viral pneumonia or hypoxia. Moderate COVID-19 symptoms incude pneumonia (fever, cough, dyspnea, fast breathing) and $\mathrm{SpO}_{2} \geq 90 \%$ on room air. Severe COVID-19 symptoms include pneumonia (fever, cough, dyspnea, fast breathing) plus respiratory rate $>30$ breaths/min, severe respiratory distress, or $\mathrm{SpO}_{2}<90 \%$ in room air. Critical COVID-19 symptoms include respiratory failure, shock, or multiorgan dysfunction. These symptoms have been observed among HCWs. Real-time polymerase chain reaction (RT-PCR; Rotor gene Q, QIAGEN, Germany) was used for the diagnosis of HCWs. A rapid diagnostic test kit for COVID-19 immunoglobulin M (IgM) and IgG antibodies (Weimi Bio-Tech) was used in seroconversion analysis. The sociodemographic characteristics of the patients, time to symptomatic progression, history of contact, use of protective equipment, clinical findings, laboratory examinations, imaging data, treatment methods, and results were retrospectively analyzed by the workplace health unit.

\section{Statistical Analysis}

Numerical, percentage, and mean distributions of the patients' sociodemographic characteristics were analyzed, and Pearson chi square analysis was performed to compare pneumonia and risk groups and sociodemographic data. Logisitic regression analysis was applied in the multivariate analysis. Statistical significance was considered at $p<0.05$. 


\section{Results}

A total of 165 (11.5\%) of 1425 HCWs who had nasopharyngeal and oropharyngeal combined SARS-CoV-2 PCR tests between March 14 and April 30 were positive among HCWs with suspected contact or symptoms. The number of SARS-CoV-2 PCR-positive cases followed in the outpatient clinic and/or hospitalized in our hospital was 4177, and 79 (3.62\%) HCWs were infected during the follow-up of the highest number of cases (2261) between April 1 and 15 (Graph 1). The average age of the HCWs who tested positive was $34.4 \pm 9.41 ; 46.1 \%$ of them were aged $18-30$ years, and $66.7 \%$ were women. The majority of HCWs with positive test results were nurses (36.3\%), and 118 (71.5\%) of the HCWs worked $40 \mathrm{~h}$ or more per week. In terms of contact, 20 (12.1\%) stated that they had contact with patients diagnosed with COVID-19 from outside the hospital in the last 14 days. In addition, 56 (33.9\%) of them had a family member diagnosed with COVID-19 after the diagnosis. In terms of comorbidity, 127 (77\%) did not have additional diseases, and 83 (50.3\%) were not smokers. The number of staff working in the high-risk department was 108 (65.5\%). Six of the HCWs had biological injuries, and 48 were in the same room when an aerosol treatment was administered to the patient. Sociodemographic data of the cases are listed in Table 1.

Approximately $47.9 \%$ of the patients were diagnosed between April 1 and 15. Considering the time of diagnosis, 24.2\% were diagnosed 6-10 days after complaints. Twenty-nine of the cases (17.6\%) were hospitalized and followed up. Depending on the disease severity, 158 (95.7\%) cases were mild-moderate, 6 cases were severe, and only 1 case was critically ill, which was followed up in the intensive care unit. No case of death was reported. Findings related to the disease are shown in Table 2. Twenty-seven (16.4\%) of the infected HCWs were asymptomatic, the most common clinical symptom was fever in $32.1 \%$, and the most common complaint was myalgia with $46.1 \%$. Computed tomography (CT) was performed in all infected HCWs, and 69 (41.8\%) were diagnosed with pneumonia by the detection of ground patchy lesions. The significant variables in the univariate analysis according to clinical findings and pneumonia status are shown in Table 3. In univariate analysis, a statistically significant difference was found between pneumonia status and the variables of age, gender, fever, myalgia, and lack of symptoms $(p<0.05)$. No significant difference was found between other variables and pneumonia $(p>0.05)$. Important variables in univariate analysis were included in the multivariate analysis. The effects of age, gender, fever, and myalgia on pneumonia were evaluated using Enter Logistic Regression analysis. Results showed that the model was significant (Table 4). An increase of one unit in age increased the effect on pneumonia with an odds ratio of 1.043-fold (95\% confidence interval: 1.006-1.082, $p<0.05)$. Among the clinical findings, fever was found to be significant in patients with pneumonia $(p<0.05)$.

On the basis of the results of the rapid antibody test performed in the first month of their diagnosis, 61.9\% had IgM and 64.3\% had IgG. Antibodies were tested in 35 patients with pneumonia, of whom 30 (85.7\%) developed antibodies, and this rate was significantly higher than those without pneumonia $(p<0.05)$.

The examination of clinical findings of HCWs in risky departments entering the patient room and exposed to aerosol procedures revealed a statistically significant difference between the patients' risk status and additional disease and pneumonia status $(p<0.05)$.

No statistically significant difference was found between the risk group and other variables $(p>0.05)$. Findings of some variables with risk group are shown in Table 5.

\section{Discussion}

HCWs worldwide have been the vulnerable and most affected risk group because of their frequent and close contact with COVID-19 patients.

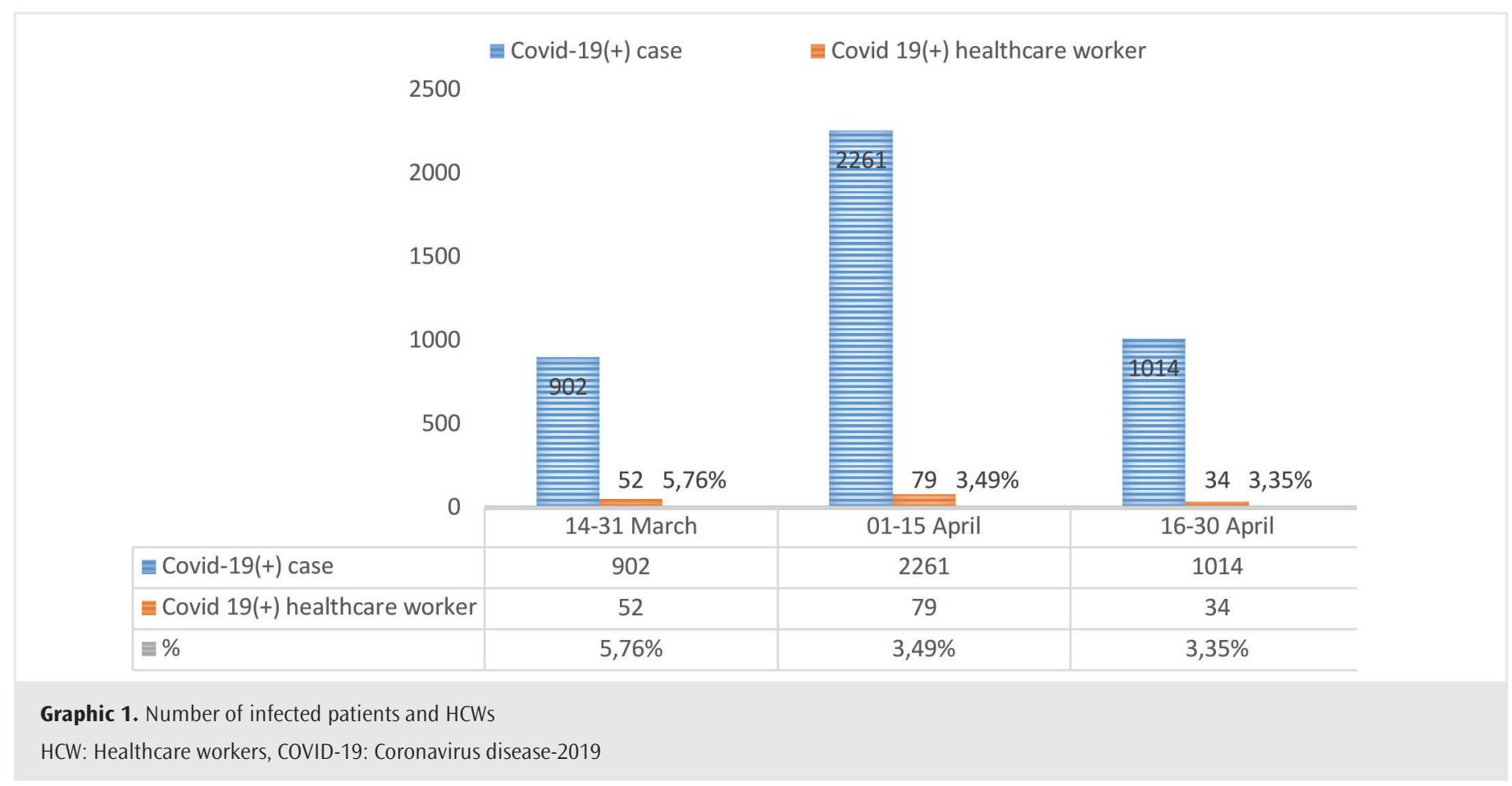


Table 1. Sociodemographic variables

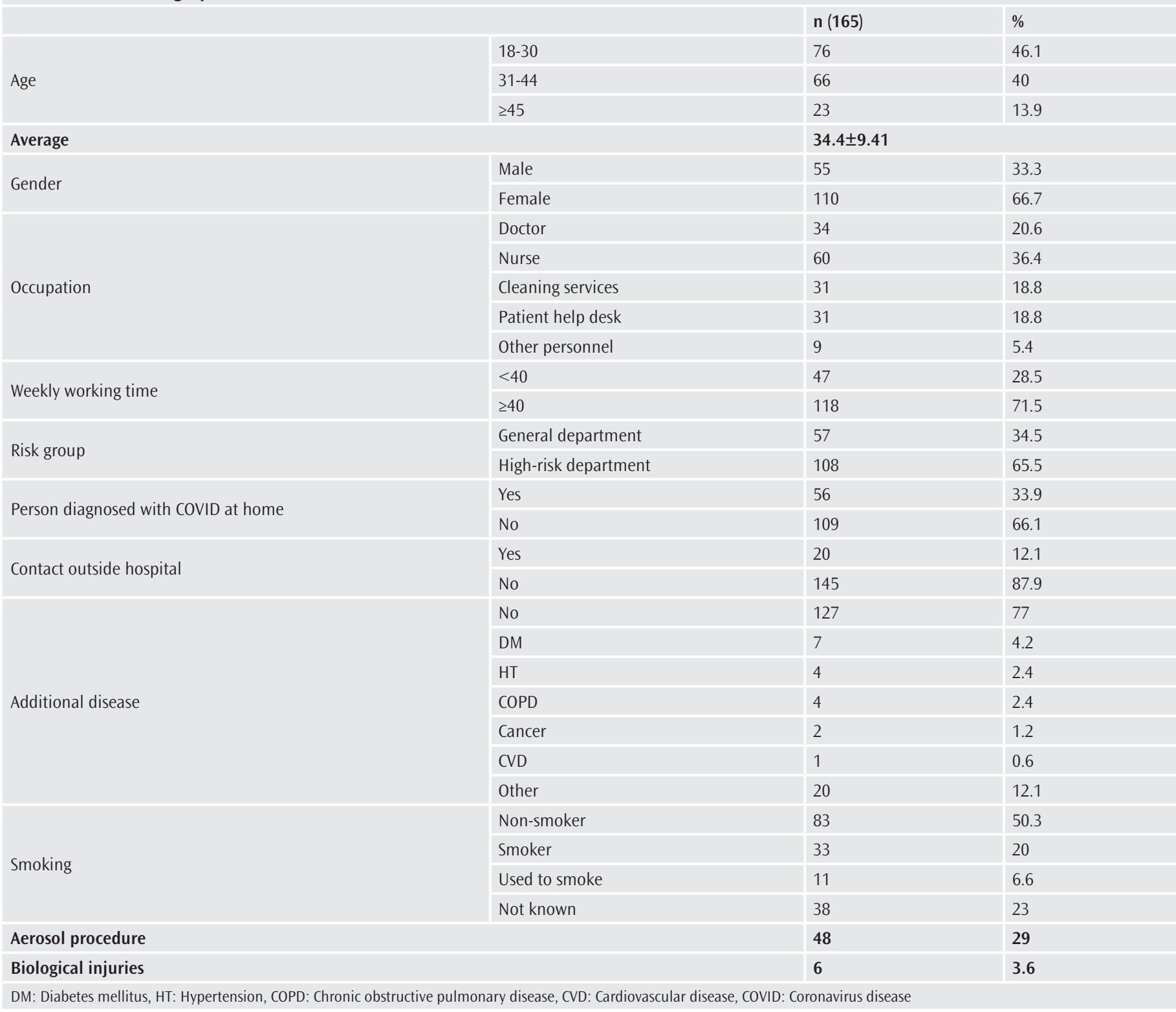

Table 2. Findings related to the disease

\begin{tabular}{|c|c|c|c|}
\hline \multirow{3}{*}{ Time of diagnosis following complaint (day) } & & \multicolumn{2}{|c|}{ n (165) } \\
\hline & $1-5$ days & 125 & $75.8 \%$ \\
\hline & 6-10 days & 40 & $24.2 \%$ \\
\hline \multirow[t]{2}{*}{ Treatment continued } & At home & 136 & $82.4 \%$ \\
\hline & No & 96 & $58.2 \%$ \\
\hline Pneumonia finding & Severe & 3 & $1.8 \%$ \\
\hline \multirow{3}{*}{ Severity of disease } & Mild & 71 & $43 \%$ \\
\hline & Moderate & 62 & $37.5 \%$ \\
\hline & Severe & 6 & $3.6 \%$ \\
\hline
\end{tabular}


Table 3. Univariate analysis of risk factors with pneumonia status

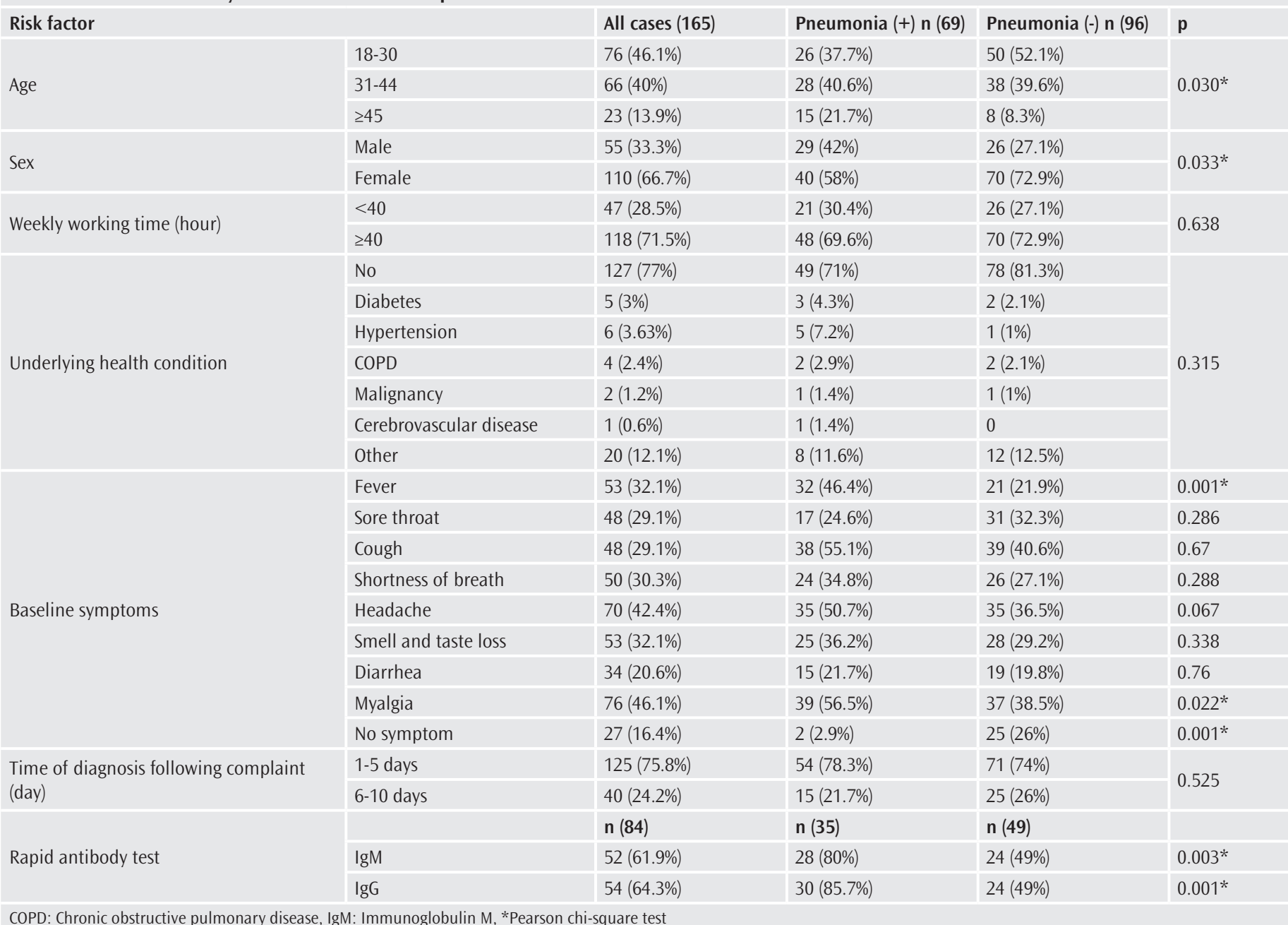

Table 4. Multivariate analysis results of the factors with an effect on pneumonia

\begin{tabular}{|l|l|l|l|l|}
\hline & p & ODDS & 95\% CI OR \\
\hline Age & & Lower & Upper \\
\hline Sex (male) & $0.023^{*}$ & 1.043 & 1.006 & 1.082 \\
\hline Fever & 0.096 & 1.831 & 0.899 & 3.731 \\
\hline Myalgia & $0.018^{*}$ & 0.420 & 0.205 & 0.862 \\
\hline Cl: Confidence interval, OR: Odds ratio & 0.063 & 0.523 & 0.264 & 1.037 \\
\hline
\end{tabular}

HCWs that had risky contact and infection can also infect other staff and patients. Early identification of asymptomatic and symptomatic HCWs is crucial to prevent virus infection from staff and maximize current workforce.

In the study conducted in the Netherlands, in the PCR testing performed between March 7 and 12 on 1353 HCWs experiencing symptoms in the last 10 days, 86 HCWs (6.4\%) were SARS-CoV-2 positive (16). In a study conducted by Keeley et al. (17) in the UK, an even higher infection rate was observed among HCWs, and 282 (18\%) of 1533 HCWs were PCRpositive; however, the contact status of the personnel has not been investigated. In our hospital, PCR was performed on 1425 HCWs who applied with COVID-19-related symptoms or who had a history of risky contact with COVID-19 cases, and 165 (11.5\%) of them were positive. Rates of SARS-CoV-2-infected HCWs vary by country, region, or even hospitals. This result may be related to many factors, such as different test procedures, infection control precaution protocols of hospitals, working conditions of HCWs, individual characteristics, number of infected cases followed, and COVID-19 prevalence of the community in the region.

At the press conference, the Minister of Health of our country stated that as of April 29, 7428 HCWs (6.5\%) were infected with SARS-CoV-2 (14). According to the world reports, this rate was $8.3 \%$ in Italy, $3.8 \%$ in China and $3 \%$ in the USA (18-20). İstanbul is the city with the highest number of cases in our country, and our hospital is one of centers with 
Table 5. Findings of some variables with risk group

\begin{tabular}{|c|c|c|c|c|}
\hline \multicolumn{2}{|l|}{ Risk factors } & $\begin{array}{l}\text { High-risk department, } \\
\text { n (108) }\end{array}$ & $\begin{array}{l}\text { General department, } \\
\text { n (57) }\end{array}$ & $\mathbf{p}$ \\
\hline \multirow{3}{*}{ Age } & $18-30$ & $54(50 \%)$ & $22(38.6 \%)$ & \multirow{3}{*}{0.327} \\
\hline & $31-44$ & $39(36.1 \%)$ & $27(47.4 \%)$ & \\
\hline & $\geq 45$ & $15(13.9 \%)$ & $8(14 \%)$ & \\
\hline \multirow{2}{*}{ Sex } & Male & $34(31.5 \%)$ & $21(36.8 \%)$ & \multirow{2}{*}{0.487} \\
\hline & Female & $74(68.5 \%)$ & $36(63.2 \%)$ & \\
\hline Weekly working time (hour) & $\geq 40$ & $82(75.9 \%)$ & $36(63.2 \%)$ & 0.084 \\
\hline \multirow{3}{*}{ Underlying health condition } & No & $89(82.4 \%)$ & $38(66.7 \%)$ & \multirow{3}{*}{$0.033^{*}$} \\
\hline & Diabetes & $2(1.9 \%)$ & $3(5.3 \%)$ & \\
\hline & Hypertension & $1(0.9 \%)$ & $5(8.8 \%)$ & \\
\hline \multirow{9}{*}{ Baseline symptoms } & Fever & $39(36.1 \%)$ & $14(24.6 \%)$ & 0.131 \\
\hline & Sore throat & $29(26.9 \%)$ & $19(33.3 \%)$ & 0.383 \\
\hline & Cough & $53(49.1 \%)$ & $24(42.1 \%)$ & 0.394 \\
\hline & Shortness of breath & $34(31.5 \%)$ & $16(28.1 \%)$ & 0.65 \\
\hline & Headache & $47(43.5 \%)$ & $23(40.4 \%)$ & 0.695 \\
\hline & Smell and taste loss & $38(35.2 \%)$ & $15(26.3 \%)$ & 0.246 \\
\hline & Diarrhea & $25(23.1 \%)$ & $9(15.8 \%)$ & 0.266 \\
\hline & Myalgia (muscle pain) & $53(49.1 \%)$ & $23(40.4 \%)$ & 0.285 \\
\hline & No symptom & $14(13 \%)$ & $13(22.8 \%)$ & 0.10 \\
\hline
\end{tabular}

the most cases in İstanbul. Between March 14 and April 30, 2020, 4177 COVID-19 cases confirmed by the laboratory were followed, and all units participated in the follow-up of COVID-19. In all COVID-19 cases followed in our hospital, the HCW rate was 3.9\%, which was lower than the rate across the country. This result could be associated with the fact that following the announcement of WHO stating that "international public health emergency" was declared on January 30 for the COVID-19 outbreak in China, the training of all staff was urgently completed before the case was reported in our country.

The total number of confirmed COVID-19 cases followed at our hospital between March 14 and 31 was 902, 5.76\% of which were HCWs. Meanwhile, HCWs constituted only 3,49\% of the 2261 patients who were followed up between April 1 and 15, when the cases were most intense. The high number of infected staff when the number of cases was low may be associated with the poor personal protection of HCWs, the poor knowledge about the pathogen, and the poor awareness of personal protection at the beginning of the pandemic.

Infected 20 HCWs reported contact with COVID-19 patients confirmed by the laboratory outside the hospital. Although $145 \mathrm{HCWs}$ have reported that they were infected in the hospital, they may also be infected by contact with presymptomatic or asymptomatic people in households or multiple environments. Countries significantly differ in the PCR testing of HCWs, and their current programs focus on symptomatic screening rather than asymptomatic staff (17). Although 27 (16.4\%) of the infected HCWs were asymptomatic, 2 cases had ground-glass appearance in thoracic $\mathrm{CT}$, and cough complaints started after the diagnosis. In the UK, PCR performed on 1032 asymptomatic HCWs showed positivity in 30 cases, and detailed examination showed that 17 cases were truly asymptomatic (21). PCR test is an important part of the diagnostic strategy, and its capacity to detect asymptomatic infection indicates the need for regular screening of all staff in the COVID unit.

Nurses were the most infected (36.3\%) among the total infected HCWs possibly becasue they are more in close contact and spend more time while giving care to patients. In addition, although the HCWs in the patient help desk (Data entry, security) had no contact with the patient rooms, they were infected at the same rate as the HCWs in cleaning services possibly because of their contact with all patients during the first admission to the hospital and insufficient use of PPE.

While long working hours increase the risk of respiratory infection, moderate working hours may benefit the health and safety of HCWs (22). 
In our hospital, $71.5 \%$ of the infected HCWs worked $40 \mathrm{~h}$ or more per week. Depending on the special role of the healthcare staff, limitations of working hours should be considered in terms of viral load during the pandemic period.

During the pandemic, HCWs can often infect the people they live with. In our study, 33.9\% of the infected HCWs also had infected family members, which increased the loss of workforce because the HCWs should take care of themsevelves and their family members. Concerns about transmitting the disease emerged with the requirement for HCWs to leave the house and the need for accommodation. Meeting the accommodation needs of HCWs during the pandemic is extremely important in preventing the spread of the disease and in reducing the loss of labor.

Among the additional measures that can reduce the risk of transmitting viruses to colleagues and patients of the infected HCWs, the Centers for Disease Control and Prevention recommends scanning all HCWs for fever and respiratory symptoms before starting their shift (20). Among the symptoms of infected HCWs in our hospital, the occurrence rate of myalgia was $46.1 \%$, headache $42.4 \%$, fever $32.1 \%$, and cough $29.1 \%$. A study conducted in a center in the Netherlands observed that the two most common symptoms among HCWs were myalgia (62\%) and headache (57\%) (16). Although these findings are subjective, screening of HCWs by questioning all findings, including headache and myalgia, at the beginning of their shift may be recommended.

Severe disease may occur in healthy individuals of any age, but predominantly advanced age or underlying medical comorbidity causes changes in the severity of the disease (23). In the general population, the rate of severe disease is $14-24.9 \%$, and the rate of critical disease is $5 \%(18,24)$

Among the infected HCWs, 6 had severe disease (3.6\%) and 1 critical $(0.6 \%)$, and 5 of these patients were over 45 years old. The reason for the low disease severity among the infected HCWs compared with the general population is associated with the average age of the employees being 34 and the incidence of comorbidities being 23\%. CT examinations were performed in all infected HCWs, and 69 (41.8\%) were diagnosed with pneumonia by the detection of ground patchy lesions. The presence of pneumonia in SARS-CoV-2-infected HCWs has been detected more frequently in men over 45 years of age and is similar to the general population (25). Of the infected HCWs, 65.5\% were employed in the high-risk department, and the incidence of pneumonia was $50.9 \%$ in this group, whereas $24.6 \%$ among those working in the general department was found statistically significant $(p=0.001)$. The frequency of pneumonia among those working in the high-risk department may be associated with high exposure to respiratory aerosol procedures. Thus, not employing HCWs with comorbidities in high-risk departments is suggested.

In patients, seroconversion usually occurs 2-4 weeks after the initial symptoms following infection with SARS-CoV-2 $(26,27)$. In our study, seroconversion was $64.3 \%$ in the rapid-format card test for antibodies performed 4 weeks after diagnosis in infected HCWs. In asymptomatic and oligosymptomatic HCWs, this rate was 49\%; in HCWs with pneumonia, seroconversion was significantly higher with $85.7 \%(p=0.001)$. Perera et al. (28) investigated seroconversion by using ELISA in PCR-positive patients, and a significant correlation was reported between disease severity and IgG formation.

\section{Study Limitations}

The limitation of our study is that long-term results are not yet available, and their follow-up continues. Not using ELISA for seroconversion can also be stated as a limitation.

\section{Conclusion}

During the epidemic, early training of HCWs on the disease, use of PPE, and infection control is extremely important to reduce the risk of infection among HCWs. Periodic screening of asymptomatic HCWs will also be beneficial to protect patients and hospital staff and prevent loss of workforce.

Ethics Committee Approval: This research protocol was approved by the University of Health Sciences Turkey, Bakırköy Dr. Sadi Konuk Training and Research Hospital Ethics Committee (approval number: 2020-10, date: 04.05.2020).

Informed Consent: All participants consisted of clinicians, nurses, and allied health personnel.

Peer-review: Externally and internally peer-reviewed.

Authorship Contributions: Surgical and Medical Practices - R.K., K.K.Y.; Concept - S.Ş., K.K.Y.; Design - Ö.P., H.K.K.; Data Collection or Processing - Ö.P., R.K.; Analysis or Interpretation - R.K., H.K.K., K.K.Y.; Literature Search - S.S..; Writing - R.K., S.S.

Conflict of Interest: No conflict of interest was declared by the authors.

Financial Disclosure: The authors declared that this study received no financial support

\section{References}

1. World Health Organization. Coronavirus. 2020. https://www.who.int/healthtopics/coronavirus\#tab=tab_1

2. Yang $X, Y u Y, X u$ J, Shu $H$, Xia J, Liu H, et al. Clinical course and outcomes of critically ill patients with SARS-CoV-2 pneumonia in Wuhan, China: a singlecentered, retrospective, observational study. Lancet Respir Med 2020; 8: 47581.

3. Coronaviridae Study Group of the International Committee on Taxonomy of Viruses. The species Severe acute respiratory syndrome-related coronavirus: classifying 2019-nCoV and naming it SARS-CoV-2. Nat Microbiol 2020; 5 : 536-44.

4. World Health Organization. WHO Director-General's opening remarks a the media briefing on COVID-19 - 11 March 2020. https://www.who.int/dg/ speeches/detail/who-director-general-s-opening-remarks-at-the-mediabriefing-on-covid-19---11-march-2020

5. World Health Organization. Coronavirus disease 2019 (COVID-19) Situation Report - 101. https://www.who.int/docs/default-source/coronaviruse/ situation-reports/20200430-sitrep-101-covid-19.pdf?sfvrsn=2ba4e093_2

6. Rebuplic of Turkey Ministry of Health. Coronavirus disease 2019 (COVID-19 Current Status. https://covid19bilgi.saglik.gov.tr/tr/

7. Chen N, Zhou M, Dong X, Qu J, Gong F, Han Y, et al. Epidemiological and clinical characteristics of 99 cases of 2019 novel coronavirus pneumonia in Wuhan, China: a descriptive study. Lancet 2020; 395: 507-13. 
8. World Health Organization. Coronavirus disease (COVID-19) Situation Report - 110 . https://www.who.int/docs/default-source/coronaviruse/situationreports/20200509covid-19-sitrep-110.pdf

9. Hamidouche M. COVID-19 outbreak in Algeria: A mathematical Model to predict cumulative cases. Bull World Health Organ. J Cont Studies Epide Publ Health 2020; 1: ep20004.

10. Sanche S, Lin $Y T, X u$ C, Romero-Severson E, Hengartner N, Ke R. High contagiousness and rapid spread of severe acute respiratory syndrome coronavirus 2. Emerg Infect Dis 2020; 26: 1470-7.

11. World Health Organization. (2020). Rational use of personal protective equipment (PPE) for coronavirus disease (COVID-19): interim guidance, 19 March 2020. World Health Organization. https://apps.who.int/iris/ handle/10665/331498

12. World Health Organization. Geneva, Switzerland: World Health Organization; 2020. WHO-China joint mission shares findings and recommendations 25 February. https://www.who.int/docs/default-source/coronaviruse/who-chinajoint-mission-on-covid-19-final-report.pdf

13. World Health Organization Geneva, Switzerland: World Health Organization; Coronavirus disease 2019 (COVID-19) Situation Report - 82. https://www.who. int/docs/default-source/coronaviruse/situation-reports/20200411-sitrep-82covid-19.pdf

14. https://www.aa.com.tr/en/health/turkey-currently-passing-over-peak-ofpandemic/1823201

15. World Health Organization. (2020). Clinical management of COVID-19: interim guidance, 27 May 2020. World Health Organization. https://apps.who.int/iris/ handle/10665/332196

16. Kluytmans-van den Bergh MFQ, Buiting AGM, Pas SD, Bentvelsen RG, van den Bijllaardt W, Oudheusden AJG, et al. SARS-CoV-2 infection in 86 healthcare workers in two Dutch hospitals in March 2020. JAMA Network Open 2020; 3: e209673.

17. Keeley AJ, Evans C, Colton H, Ankcorn M, Cope A, State A, et al. Roll-out of SARS-CoV-2 testing for healthcare workers at a large NHS Foundation Trust in the United Kingdom, March 2020. Euro Surveill 2020; 25: 2000433.
18. Wu Z, McGoogan JM. Characteristics of and important lessons from the Coronavirus disease 2019 (COVID-19) outbreak in china: summary of a report of 72314 cases from the chinese center for disease control and prevention. JAMA 2020; 323: 1239-42.

19. https://www.dailymail.co.uk/news/article-8129499/More-2-600-medicalworkers-infected-coronavirus-Italy.html

20. CDC COVID-19 Response Team. Characteristics of health care personnel with COVID-19 - United States, February 12-April 9, 2020. MMWR Morb Mortal Wkly Rep 2020; 69: 477-81.

21. Rivett L, Sridhar S, Sparkes D, Routledge M, Jones NK, Forrest S, et al. Screening of healthcare workers for SARS-CoV-2 highlights the role of asymptomatic carriage in COVID-19 transmission. Elife 2020; 9: e58728.

22. Weaver MD, Landrigan CP, Sullivan JP, O'Brien CS, Qadri S, Viyaran N, et al. The association between resident physician work hour regulations and physician safety and health. Am J Med 2020; 133: 343-54.

23. Zhou F, Yu T, Du R, Fan G, Liu Y, Liu Z, et al. Clinical course and risk factors for mortality of adult inpatients with COVID-19 in Wuhan, China: a retrospective cohort study. Lancet 2020; 395: 1054-62.

24. Livingston E, Bucher K. Coronavirus disease 2019 (COVID-19) in Italy. JAMA; 2020; 323: 1335.

25. Ran L, Chen X, Wang Y, Wu W, Zhang L, Tan X. risk factors of healthcare workers with Coronavirus disease 2019: a retrospective cohort study in a designated hospital of Wuhan in China. Clin Infect Dis 2020; 71: 2218-21.

26. Petherick A. Developing antibody tests for SARS-CoV-2. Lancet 2020; 395: 1101-2.

27. Okba NMA, Müller MA, Li W, Wang C, GeurtsvanKessel CH, Corman VM, et al. Severe Acute Respiratory Syndrome Coronavirus 2-Specific Antibody Responses in Coronavirus Disease Patients. Emerg Infect Dis 2020; 26: 1478-88.

28. Perera RA, Mok CK, Tsang OT, Lv H, Ko RL, Wu NC, et al. Serological assays for severe acute respiratory syndrome coronavirus 2 (SARS-CoV-2), March 2020. Euro Surveill 2020; 25: 2000421. 